\title{
Corporate growth through mergers and acquisitions: Viable strategy or road to ruin?
}

\author{
P. Brews \\ Graduate School of Business Administration, University of the Witwatersrand, P.O. Box 31170 \\ Braamfontein 2017, Republic of South Africa
}

Received 5 March 1986; accepted 5 September 1986

\begin{abstract}
Comorate growth through mergers and acquisitions is a strategy adopted by many South African companies to achieve their growth objectives. However, research in both the United Kingdom and the United States of America has found that most mergers and acquisitions do not meet expectations. Many fail and are divested, at considerable human and financial cost. To date, little research on the viability of growth through mergers and acquisitions has been done in South Africa. In the light of this, in-depth interviews were recently held with 20 senior South African executives, concerning the practices adopted by their organizations in the execution of mergers and acquisitions. This article presents the findings of the research in three specific areas: the formulation of a merger and acquisition strategy; the formulation of an acquisition profile; and the viability and critical success factors in adopting a growth through mergers and acquisitions strategy. Broadly speaking, it was found that the sample interviewed had a good understanding of the acquisition profile, but tended to be less focused in their reasons why their organizations elected to pursue a growth through merger and acquisition strategy. In addition, mergers or acquisitions seem to be more successful in the South African context than in other countries, where similar research has been conducted. A number of reasons for success or failure enumerated in the literature were confirmed. The main finding was that corporate growth through mergers and acquisitions can be either a viable strategy or road to ruin. Companies that systematically plan and manage their merger or acquisition programmes are likely to be successful; ad hoc approaches are likely to fail. The article provides aspects of a framework within which such a merger or acquisition programme may be structured to ensure success.
\end{abstract}

Korporatiewe groei deur middel van oomames en samesmeltings is 'n strategie wat deur baie Suid-Afrikaanse maatskappye aanvaar word om hul doelstellings te bekom. Dog navorsing in beide die V.S.A. en Engeland toon dat meeste oomames om samesmeltings nie verwagtinge bevredig nie. Baie faal en word gedisinvesteer, teen aansienlike menslike en finansiéle koste. Tot op datum is nie veel navorsing op die lewensvatbaarheid van groei deur samesmeltings en oornames in Suid Afrika gedoen nie. Daarom is onlangs samesprekinge in diepte gevoer met 20 senior Suid-Afrikaanse uitvoerende beamptes, na die proses wat deur hulle organisasies in dlé verband aanvaar word. Hierdie artikel toon die bevindinge van die navorsing in drie areas aan: die formulering van 'n groeistrategie deur middel van oomames en samesmeltings, die formulering van ' $n$ oomameprofiel, en die lewensvatbaarheid en kritiese suksesfaktore in die aanvaarding van 'n samesmeltings- en oomamegroeistrategie. Oor die algemeen het dit geblyk dat die toetsmonster 'n goele begrip van die oomameprofiel getoon het, maar geneig het om minder aandag te spandeer aan die redes waarom hulle organisasies 'n strategie van groei deur middel van samesmelting en oorname gekies het. Daarbenewens, skyn oomames en samesmelting in Suid-Afrika meer suksesvol te wees dan in ander lande, waar soortgelyke opnames gedoen is. ' $n$ Aantal redes vir die sukses al dan nie, soos reeds in die literatuur aangedui, is bevestig. Die hoofbevinding was dat korporatiewe groei deur middel van oomames en samesmeltings of 'n lewensvatbare strategie kan wees of dat dit ' $n$ afdraende pad mag wees. Maatskappye wat sistematies die oomames en samesmeltings beplan en beheer is meer suksesvol; en ad hoc-benaderings is minder geslaagd. Hierdie artikel voorsien aspekte van 'n raamwerk waarbinne 'n program van suksesvolle oomames en samesmeltings gestruktureer kan word.

\section{Introduction}

Analysis of some of the titles of articles written on the execution of mergers and acquisitions over the past fifteen years or so reveals a disturbing trend. Many have negative leanings, as if for some reason the topic is fatally flawed, or fraught with difficulty. 'Why do mergers miscarry?' was the question asked by Kitching (1967). Farrant (1970), implying there was something inherently furtive or deceptive about the topic, promised to reveal 'The truth about mergers'. Levinson (1970) put his professional skills to work in 'A psychologist diagnoses merger failure', whilst Foulder and Gill (1978) talked about 'Managing the merger: the acquisition and the aftermath', as if an acquisition was akin tosome natural disaster, leaving a trail of want and destruction in its wake.

Reading some of the articles is even more disquieting. The truth of the matter is that according to the literature, many of the transactions undertaken simply do not meet expectations. Many fail, given that it is inherently difficult to define success or failure in this context. Rockwell (1968), quoting a study done on the subject, reported that only 64 out of 120 companies making acquisitions would acquire the companies they did if they had the chance again. Farrant (1970) asserted that only one in nine mergers succeeded in Britain. Peters and Waterman (1982: 293), stated that most acquisition goawry; expected synergies are seldom realized; all that remains is a shell and some devalued capital equipment. Jacobs (1984) concluded one third of mergers undertaken end up in divestment or liquidation, and $70 \%$ fail to meet expectations. Rowlinson (1984) investigated the course of events of six private companies after they had been acquired by companies listed on the Johannesburg Stock Exchange. Five of these companies, after a relatively short time, were disposed of. Swaim (1985) concluded one in five acquisitions were 
successful. Growth by merger or acquisition, it seems, is a risky business.

Much of the literature began emerging in the late sixties, perceptive testimony to the merger mania and conglomeration which characterized corporate life at that time. Rappaport (1979: 99) referred to the 1960s in America as a time of 'frantic merger activity', prompted according to Macgregor (1979) by rigorous anti-trust enforcement in that country. South Africa did not escape the fad either. The Stock Exchange boom of the late sixties, and the activities of the Slater Walker's, Jessel Securities, and the like saw merger activity increase dramatically over that time (Macgregor, 1979: 74).

The shortcomings of conglomeration as a form of corporate organization have long since been recognized. They are not difficult to determine. Organizations that enthusiastically acquire other businesses unrelated to their own (the essence of conglomeration) soon discover they lack the management skills, knowledge, and experience to manage these businesses:

'Conglomerate enterprises rarely, if ever, bring any relevant managerial, technical or marketing skills to the enterprises they acquire, for the simple reason that they have no direct knowledge of these unrelated businesses'. (Reich, 1983: 146)

Unchannelled diversification, internally or externally, as a strategy, has also been shown by Gort, Rumelt, and Haugen and Langetieg (cited in Peters \& Waterman, 1982) to be an unattractive proposition in numerous academic studies. But help is close at hand. In response to the hiatus of the sixties and seventies, the topic of mergers and acquisitions, and more particularly topics such as how to successfully plan, execute, and integrate mergers and acquisitions, prompted a proliferation of books and articles. Rockwell (1968), producing one of the earliest landmark articles, looked at 'How to acquire a company'. Leighton \& Tod (1969) dealt with 'After the acquisition: Continuing challenge', whilst Searby (1969) shortly thereafter focused on the issue of how to 'Control post merger change'. Blake and Mouton (1984) dealt with 'How to achieve integration on the human side of the merger'.

By 1985, Willensky (1985: 77), in an article 'Making it happen: How to execute an acquisition', reported that the only aspect regarding mergers and acquisitions still needing exploration in the literature related to the period between planning and integration, indeed everything from 'contacting the prospective parties to signing the final papers'. He then promptly 'explored' this period with gusto! In short, the theoretical body of knowledge has expanded somewhat since the dark days of the freewheeling, conglomerate sixties. Much has been explained, and much has been learnt about the practice of mergers and acquisitions. Traversing such diverse fields as finance, human behaviour, corporate strategy, and organization design and development, a body of knowledge has evolved that should, in theory, reduce the risk of merging or acquiring, and indeed produce a different set of statistics from those mentioned above.

In the light of this, a study of the perceptions and practices adopted by 20 companies actively involved in mergers and acquisitions was recently undertaken in South
Africa. The purpose of this article is to present and discuss certain of the findings of this research. It is based upon responses obtained in interviews recently held with senior executives from these companies.

In the design of the research, the field of mergers and acquisitions was divided into three key decision areas. These areas are outlined in Figure 1.

Stage I encompasses the determination of an acquisition strategy. This involves deciding which industries and types of businesses should be acquired; how much cash resources should be devoted to an acquisition programme; the location and characteristics of potential candidates; and so on.

Stage II encompasses the screening and evaluation of potential candidates. This involves deciding who will do the evaluation - corporate employees or outsiders; which aspects need to be focused on in the evaluation process; and how much importance should be attached to each of these aspects.

Stage III deals with the implementation and integration of mergers and acquisitions - how does one integrate and implement a transaction successfully?

The focus of this article is Stage I - the determination of an acquisition strategy. Stages II and III will be dealt with in other articles. This article also investigates two other issues: how successful are mergers and acquisitions in the South African context; and what are the critical factors contributing to their success or failure?

Interviews were held with 20 senior executives drawn from a random sample of prominent South African companies. Of these executives, four were managing directors, ten were members of the board other than the managing director, and six were senior executives in their organizations. All had extensive experience in the field of mergers and acquisitions. In fact:

- seven had been involved with between 3-6transactions; - two had been involved with between 7-10 transactions; and

- eleven had been involved with more than 10 transactions.

Table 1 provides in-depth data on each respondent and the organization he represented.

\section{Research methodology}

Based on the relevant literature, a semi-structured questionnaire of five sections was constructed and administered. These five sections were Biographical Information; Acquisition Strategy and Profile; Acquisition Evaluation; Acquisition Implementation; and General. This article

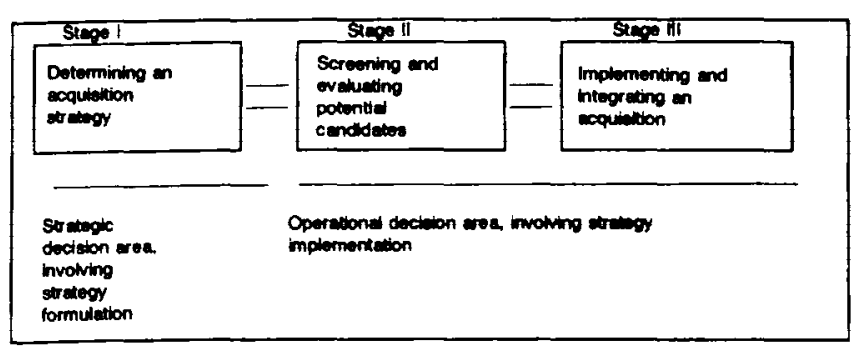

Figure 1 Decision areas in mergers and acquisitions 
Tablo 1 Respondent/organization characteristics

\begin{tabular}{|c|c|c|c|c|c|c|}
\hline \multicolumn{4}{|c|}{ Respondent characteristics } & \multicolumn{3}{|c|}{ Organization characteristics } \\
\hline Position & $\begin{array}{l}\text { Years } \\
\text { Service }\end{array}$ & $\begin{array}{c}\mathbf{M} \& \mathbf{A} \\
\text { Involvement }\end{array}$ & Capacity & $\begin{array}{l}\text { Turnover } \\
\text { (Rm) }\end{array}$ & $\begin{array}{l}\text { Legal } \\
\text { Status }\end{array}$ & Description \\
\hline $\begin{array}{l}\text { Senior } \\
\text { Management }\end{array}$ & $1-5$ yrs & $\begin{array}{c}>10 \text { Trans- } \\
\text { actions }\end{array}$ & $\begin{array}{l}\text { Advisor } \\
\text { to the } \\
\text { ecquiror }\end{array}$ & $>25$ & $\begin{array}{l}\text { Public } \\
\text { listed }\end{array}$ & $\begin{array}{l}\text { Widely diversified } \\
\text { conglomerate with } \\
\text { investments in } 10 \\
\text { sectors of the JSE }\end{array}$ \\
\hline Director & $>5$ yrs & $\begin{array}{l}>10 \text { Trans- } \\
\text { actions }\end{array}$ & $\begin{array}{l}\text { Director } \\
\text { in charge } \\
\text { of acqui- } \\
\text { sitions }\end{array}$ & $>25$ & $\begin{array}{l}\text { Public } \\
\text { listed }\end{array}$ & $\begin{array}{l}\text { Investments in the } \\
\text { Engineering sector } \\
\text { of the JSE }\end{array}$ \\
\hline Director & $1-5$ yrs & $\begin{array}{l}>10 \text { Trans- } \\
\text { actions }\end{array}$ & $\begin{array}{l}\text { Group ops } \\
\text { director, } \\
\text { responsible } \\
\text { for identi- } \\
\text { fication, } \\
\text { evaluation } \\
\text { and } \\
\text { implement- } \\
\text { ation of } \\
M \text { A's }\end{array}$ & $>25$ & $\begin{array}{l}\text { Public } \\
\text { listed }\end{array}$ & $\begin{array}{l}\text { Widely diversified } \\
\text { conglomerate }\end{array}$ \\
\hline Director & $>5$ yrs & $\begin{array}{l}>10 \text { Trans- } \\
\text { actions }\end{array}$ & $\begin{array}{l}\text { All aspects } \\
\text { of } M \text { \&'s }\end{array}$ & $>25$ & $\begin{array}{l}\text { Public } \\
\text { liated }\end{array}$ & $\begin{array}{l}\text { Widely diversified } \\
\text { conglomerate }\end{array}$ \\
\hline $\begin{array}{l}\text { Senior } \\
\text { Management }\end{array}$ & $1-5$ yrs & $\begin{array}{c}\text { 3-6 Trans- } \\
\text { actions }\end{array}$ & $\begin{array}{l}\text { Identifier } \\
\text { and analyst } \\
\text { of } M \& A^{\prime} s\end{array}$ & $>25$ & $\begin{array}{l}\text { Public } \\
\text { listed }\end{array}$ & $\begin{array}{l}\text { Widely diversified } \\
\text { conglomerate }\end{array}$ \\
\hline $\begin{array}{l}\text { Senior } \\
\text { Management }\end{array}$ & $>5 \mathrm{yrs}$ & $\begin{array}{l}>10 \text { Trans } \\
\text { actions }\end{array}$ & $\begin{array}{l}\text { All aspects } \\
\text { of } M \& A ' s\end{array}$ & $>25$ & $\begin{array}{l}\text { Public } \\
\text { listed }\end{array}$ & $\begin{array}{l}\text { Widely diversified } \\
\text { conglomerate }\end{array}$ \\
\hline Director & $>5 \mathrm{yrs}$ & $\begin{array}{l}>10 \text { Trans- } \\
\text { actions }\end{array}$ & $\begin{array}{l}\text { Head Office } \\
\text { link for } \\
\text { motivation, } \\
\text { approval } \\
\text { and } \\
\text { control }\end{array}$ & $>25$ & $\begin{array}{l}\text { Public } \\
\text { un- } \\
\text { listed }\end{array}$ & Not disclosed \\
\hline Director & $>5$ yrs & $\begin{array}{l}>10 \text { Trane } \\
\text { actions }\end{array}$ & $\begin{array}{l}\text { Group } \\
\text { acquisition } \\
\text { committec } \\
\text { member }\end{array}$ & $>25$ & $\begin{array}{l}\text { Public } \\
\text { listed }\end{array}$ & $\begin{array}{l}\text { Investments in the } \\
\text { Engineering sector } \\
\text { of the JSE }\end{array}$ \\
\hline Director & $>5 \mathrm{yrs}$ & $\begin{array}{l}>10 \text { Trans- } \\
\text { actions }\end{array}$ & $\begin{array}{l}\text { Advisor to } \\
\text { parties in } \\
\text { M \& A's }\end{array}$ & $>25$ & $\begin{array}{l}\text { Public } \\
\text { un- } \\
\text { listed }\end{array}$ & $\begin{array}{l}\text { Financial } \\
\text { Institution }\end{array}$ \\
\hline Director & $1-5$ yrs & $\begin{array}{l}>10 \text { Trans- } \\
\text { actions }\end{array}$ & $\begin{array}{l}\text { Consultant, } \\
\text { negotiator }\end{array}$ & $>25$ & $\begin{array}{l}\text { Public } \\
\text { listed }\end{array}$ & $\begin{array}{l}\text { Involved in Paper } \\
\text { \& Packaging } \\
\text { Printing \& } \\
\text { Publishing sec- } \\
\text { tors of the JSE }\end{array}$ \\
\hline $\begin{array}{l}\text { Managing } \\
\text { Director }\end{array}$ & $1-5$ yrs & $\begin{array}{l}\text { 3-6 Tran- } \\
\text { actions }\end{array}$ & $\begin{array}{l}\text { All aspects } \\
\text { of M \& S's }\end{array}$ & $>25$ & $\begin{array}{l}\text { Private } \\
\text { ab. of } \\
\text { listed } \\
\text { Co. }\end{array}$ & $\begin{array}{l}\text { Involved in the } \\
\text { Chemical \& Oil } \\
\text { sector of the } \\
\text { JSE }\end{array}$ \\
\hline $\begin{array}{l}\text { Senior } \\
\text { Management }\end{array}$ & $>5$ yrs & $\begin{array}{l}\text { 7-10 Trans- } \\
\text { actions }\end{array}$ & $\begin{array}{l}\text { Strategic } \\
\text { planner of } \\
\text { M \& A's }\end{array}$ & $>25$ & $\begin{array}{l}\text { Public } \\
\text { linted }\end{array}$ & Not dicclosed \\
\hline $\begin{array}{l}\text { Senior } \\
\text { Management }\end{array}$ & $>1 \mathrm{yr}$ & $\begin{array}{l}>10 \text { Trans- } \\
\text { actions }\end{array}$ & $\begin{array}{l}\text { All aspects } \\
\text { of M \& A's }\end{array}$ & $>25$ & $\begin{array}{l}\text { Public } \\
\text { listed }\end{array}$ & Mining House \\
\hline
\end{tabular}


Table 1 Continued

\begin{tabular}{|c|c|c|c|c|c|c|}
\hline \multicolumn{4}{|c|}{ Respondent characteristics } & \multicolumn{3}{|c|}{ Organization characteristic } \\
\hline Position & $\begin{array}{l}\text { Years } \\
\text { Service }\end{array}$ & $\begin{array}{c}\text { M \& A } \\
\text { Involvement }\end{array}$ & Capacity & $\begin{array}{l}\text { Turnover } \\
\text { (Rm) }\end{array}$ & $\begin{array}{l}\text { Legal } \\
\text { Status }\end{array}$ & Description \\
\hline $\begin{array}{l}\text { Managing } \\
\text { Director }\end{array}$ & $>5$ yrs & $\begin{array}{l}\text { 3-6 Trans- } \\
\text { actions }\end{array}$ & $\begin{array}{l}\text { All aspects } \\
\text { of } M \& A ' s\end{array}$ & $>25$ & $\begin{array}{l}\text { Public } \\
\text { listed }\end{array}$ & $\begin{array}{l}\text { Industrial Holding } \\
\text { Company }\end{array}$ \\
\hline Director & $>5$ yrs & $\begin{array}{l}>10 \text { Trans- } \\
\text { actions }\end{array}$ & $\begin{array}{l}\text { All aspects } \\
\text { of } M \& A ' s\end{array}$ & $>25$ & $\begin{array}{l}\text { Public } \\
\text { listed }\end{array}$ & Conglomerate \\
\hline $\begin{array}{l}\text { Senior } \\
\text { Management }\end{array}$ & $>5$ yrs & $\begin{array}{l}>10 \text { Trans- } \\
\text { actions }\end{array}$ & $\begin{array}{l}\text { All aspects } \\
\text { of } M \& A^{\prime} s\end{array}$ & $>25$ & $\begin{array}{l}\text { Public } \\
\text { listed }\end{array}$ & $\begin{array}{l}\text { Multi-national } \\
\text { conglomerate }\end{array}$ \\
\hline Director & $1-5$ yrs & $\begin{array}{l}\text { 3-6 Trans- } \\
\text { actions }\end{array}$ & $\begin{array}{l}\text { All aspects } \\
\text { of } M \& A ' s\end{array}$ & $>25$ & Private & $\begin{array}{l}\text { Private company } \\
\text { operating in the } \\
\text { Transport \& Motor } \\
\text { sectors of the JSE }\end{array}$ \\
\hline $\begin{array}{l}\text { Deputy } \\
\text { Chairman }\end{array}$ & $>5$ yrs & $\begin{array}{c}\text { 3-6 Trans- } \\
\text { actions }\end{array}$ & $\begin{array}{l}\text { Joint Co- } \\
\text { ordinator \& } \\
\text { negotiator }\end{array}$ & $>5<25$ & $\begin{array}{l}\text { Public } \\
\text { listed }\end{array}$ & $\begin{array}{l}\text { Mining } \\
\text { organization }\end{array}$ \\
\hline $\begin{array}{l}\text { Managing } \\
\text { Director }\end{array}$ & $>5$ yrs & $\begin{array}{l}\text { 3-6 Trans- } \\
\text { actions }\end{array}$ & $\begin{array}{l}\text { All aspects } \\
\text { of } M \& A \text { 's }\end{array}$ & $>5<25$ & Private & $\begin{array}{l}\text { Involved in cos- } \\
\text { metics industry }\end{array}$ \\
\hline $\begin{array}{l}\text { Managing } \\
\text { Director }\end{array}$ & $>5$ yrs & $\begin{array}{l}\text { 3-6 Trans- } \\
\text { actions }\end{array}$ & $\begin{array}{l}\text { All aspects } \\
\text { of } M \& \text { A's }\end{array}$ & $><25$ & $\begin{array}{l}\text { Public } \\
\text { listed }\end{array}$ & $\begin{array}{l}\text { Engineering } \\
\text { trading company }\end{array}$ \\
\hline
\end{tabular}

addresses the replies received to the first, second, and fifth sections. The responses to the second and third sections (Acquisition Evaluation and Acquisition Implementation) will be dealt with in other articles.

Section One of the questionnaire (Biographical Information) was designed to discover the characteristics of the companies represented by the respondents, and the personal profile of respondents themselves. Both these issues are important, since the level and background of the respondents is of obvious importance to the weight that can be attached to their responses.

Section Two of the questionnaire (Acquisition Strategy and Profile) was designed to discover information about the acquisition strategy and profile of the companies represented. This section included questions on whether or not the companies represented had formally adopted a growth by acquisition strategy, and whether or not such companies had developed an explicit acquisition profile. The content of the acquisition profile was also explored. In this regard, the acquisition profile was divided into six key characteristics:

- nature of business/industry;

- the amount available;

- the location of the business;

- the management policy with respect to acquired management;

- the required return on investment; and

- minimum/maximum size of investment criteria.

Respondents were also asked to list any other criteria they considered important.

Section Two also included questions on past transactions, which were divided into six categories. Respondents were requested to generally classify the transactions they had been involved in.

Section Five of the questionnaire tested the respondents' perceptions of the successes/failures of past transactions, and the reasons for these successes/failures.

The research does not claim to be representative of all parties involved in the practice of mergers or acquisitions in South Africa. However it is hoped that the article represents, at the least, an overview of the major strategic issues which should be taken into account by any parties wishing to embark upon a growth by merger or acquisition strategy. In addition, it should provide an honest appraisal of the practical problems encountered in adopting such a strategy, and the perceptions and practices of twenty active acquisitors in South Africa.

\section{Acquisition strategy and profile}

The starting point of any acquisition programme should be a review of corporate objectives and product-market strategies for various strat egic business units (Rappaport, 1979: 100). In essence, this involves a systematic appraisal of corporate business objectives, areas of future growth, corporate strengths and weaknesses, and an analysis of the environment within which the organization operates (Rappaport, 1979). Kitching (1967: 91) asserts :

'Companies that merely react to opportunities to purchase are less successful in their acquisitions than those with an overall strategy which includes an acquisition programme ... Successful companies formulate a set of acquisition criteria which are consistent with overall strategy, and then rigorously apply them'.

Therefore, once a decision is taken to pursue a strategy of growth by merger or acquisition, an acquisition strategy 
should be developed. Broadly speaking, the formulation of such a strategy starts, as noted above, with corporate introspection, and culminates in the framing of an acquisition profile, which is discussed in depth.

The first question asked of respondents was whether or not their organizations had formally adopted a growth by acquisition strategy. Eleven responded their organizations had, eight responded their organizations had not, and one replied 'yes and no', creating for himself his own category. Those who indicated their organizations had formally adopted a growth by acquisition strategy were asked to explain why. The following reasons were advanced:

- our company is a conglomerate - historically this has been our growth strategy (three respondents);

- it's part of our total growth strategy (two respondents); - it's cheaper to buy than to build, and we are cash rich which puts us in a strong negotiating position (two respondents);

- our business offers considerable economies of scale;

- the major shareholder and chairman have 'tremendous skills' in this area, and acquisitions have become part of our corporate culture and one of our main strengths;

- our existing markets are mature, with low margins - we look to acquisitions to provide us yield sweeteners;

- we want to achieve a size, structure, and share spread so the developers of the company can withdraw without detrimentally affecting the share price; and

- our company cannot grow any bigger by internal/organic means - it is often better to enter new markets by acquisition, than by new entry.

Only three of the reasons were mentioned more than once, and a number of different motivations were given explaining the adoption of a growth by acquisition strategy. For this reason it is difficult to discern any common thread as to why organizations adopt such a strategy.

The next step in the development of an acquisition strategy involves the formulation of an acquisition profile, which represents a systematic listing of those criteria any acquisition should meet before being considered a potential acquisition candidate. Ideally, this profile should be constructed prior to embarking upon an acquisition programme, taking into account organization objectives, strategies, and resources. All major elements in the organization (Marketing, Finance, Production, Personnel, etc.), should be involved in its determination. The exercise is essentially an integrative one.

Conceptually, it is possible to develop an acquisition profile without having formally adopted a growth by acquisition strategy. This was in fact confirmed by the survey. Although eight respondents indicated they had not formally adopted a growth by acquisition strategy, only six indicated their organizations had not developed an acquisition profile.

Fourteen of the twenty respondents indicated their organizations had developed and adopted an express acquisition profile. Regarding the specific contents of the profiles, of these fourteen organizations:

- thirteen had developed a policy regarding the required rate of return a potential acquisition should meet;
- twelve had specified the nature of business/industry potential candidates should be involved in before being considered;

- eleven had an espoused policy regarding the management of the acquired company;

- ten had developed maximum/minimum criteria regarding the size of any potential investment;

- six had specified preferred locations; and

- five had considered the amount available to be spent on acquisitions, placing this criterion lowest on the list of priorities.

A number of other profile criteria were mentioned. These included consideration of the future growth potential of a candidate, including the growth potential of the markets the candidate was serving (five respondents); the degree of labour/capital intensity evidenced by the candidate, together with the industrial relations record and wage structures; the compatibility of pension fund/housing loan policies; the potential for rationalization; and the degree of market share enjoyed by a candidate - only those with a 'fairly substantial' market share would be considered.

One can conclude from this that at least the concept of an acquisition profile was known to a majority of respondents, with many of the criteria contained in the questionnaire being included in most of the acquisition profiles developed. Regarding 'other' criteria, future growth potential was considered important.

The six respondents whose organizations did not have an acquisition profile were asked to explain why this was the case. The following reasons were advanced:

- we do not have a growth by acquisition strategy, and therefore no planning is done in this regard (two respondents);

- our company is not big enough to have an acquisition profile;

- an acquisition profile would place unnecessary constraints on the entrepreneur leading the group - it would not fit the dynamic nature of our group whose criteria change constantly to fit specific goals and circumstances; and

- our acquisition profile is somewhat 'ad hoc', and depends on changing circumstances.

Some of these reasons are to be viewed with caution. Size, firstly, should not be the criterion used to decide whether or not a company develops an acquisition profile. Secondly, no planning, or ad hoc planning, in the merger or acquisition process is a sure recipe for disaster. It is not the frequency that an organization engages in a merger or acquisition, or whether or not a formal growth by merger or acquisition strategy has been adopted, which counts. The fact that an organization is involved in such an exercise just once requires planning and forethought. 'Ad hoc' acquisitions are likely to result in 'ad hoc' failures. The major criteria in an acquisition profile will now be discussed in more depth.

\section{Nature of business/industry}

This represents perhaps the most important characteristic of the acquisition profile. It sets out the nature of business any candidate should be engaged in before being considered a potential acquisition. One of the eight attributes which emerged from the analysis of the 62 excellent corporations in 'In search of excellence' was that these corporations 'stick to the knitting': 
'Robert W Johnson, former Johnson and Johnson Chairman put it this way. "Never acquire a business you don't know how to run!" Or as Edward G Harness, past Chief Executive at Proctor and Gamble, said, "This Company has never left its base. We seek to be everything but a conglomerate." While there are a few exceptions, the odds for excellent performance seem strongly to favour those companies that stay reasonably close to businesses they know.' (Peters \& Waterman, 1982: 15).

Peters and Waterman also found that :

- virtually all the growth in the excellent companies was internally generated and home grown;

- firms that branch out (either by acquisition or internal diversification) but stick to the knitting out-perform the others; and

- firms that branch into related fields are likely to be less successful, whilst those that diversify in a variety of fields are likely to be least successful.

Therefore the nature of business potential candidates should be involved in is a crucial consideration. Table 2 presents the findings of the research regarding the nature of business/industry the respondents required prospective candidates to be involved in before being considered.

The lessons, apparently, have been learnt. Most organizations specify that candidates should be either in the same business/industry or a related business/industry before being considered. Most of the conglomerates in the sample, it seems, are now only prepared to invest further in industries/businesses they know. Interestingly enough, none of the sample indicated he was prepared to acquire unrelated businesses alone, whilst only two indicated they would consider acquiring unrelated businesses in combination with others.

Respondents were also asked to generally categorize the past mergers and acquisitions their organizations had been involved in. Kitching's classification (1967) of such transactions was used:

- horizontal: where the companies merged with/ acquired were in the same industry, with approximately the same customers and suppliers;

- vertical integration: where the companies merged with/acquired were either major suppliers or customers of the offeror company - this can be more finely defined as backward or forward vertical integration, where backward refers to the acquisition of sources of supply, and forward to the acquisitions of customers or markets (Robinson, 1958);

- concentric marketing: where the companies merged with/acquired have similar customer types, but different technologies;

- concentric technology: where the companies merged with/acquired have similar technologies, but different customer types; and

- conglomerates: where the customers and technology of the two companies are unrelated (in the questionnaire this was labelled 'none of the above').

Table 3 tabulates the research findings in this regard.

The clustering is fairly clear. Most of the organizations' past mergers/acquisitions, generally speaking, were either horizontal or vertical integration, with horizontal integration being the most prevalent, and vertical backward integration the second most prevalent category of transaction. Interestingly enough, Kitching's study (1967) revealed a different pattern in the United States of America at that time, where in a study of 69 transactions:

- 3\% were classified vertical integration;

$-25 \%$ were classified horizontal;

- $13 \%$ were classified concentric marketing;

- $14 \%$ were classified concentric technology; and

- $45 \%$ were classified conglomerate.

Although the comparison is not strictly valid (comparing studies done at different times on different bases) the discrepancies are clearly apparent.

Amount available

Of the specific criteria included in the acquisition profile, amount available was accorded the lowest priority. Nine

Table 2 Nature of business/industry specified in acquisition profiles

Nature of profile

Respondent No.

\begin{tabular}{|c|c|c|c|c|c|c|c|c|c|c|c|c|c|c|c|c|c|c|c|c|}
\hline & 1 & \multicolumn{2}{|c|}{23} & 4 & 5 & 6 & 7 & 8 & 9 & 10 & 11 & 12 & 13 & 14 & 15 & 16 & 17 & 18 & 19 & 20 \\
\hline $\begin{array}{l}\text { Same as present nature of } \\
\text { business/industry }\end{array}$ & $\mathbf{x}^{1}$ & $\mathbf{x}$ & - & & & & - & $\mathbf{x}$ & $\mathbf{x}$ & - & & & & $\mathbf{x}$ & - & $x$ & $\mathbf{x}$ & - & $\mathbf{x}$ & - \\
\hline $\begin{array}{l}\text { Related to present nature } \\
\text { of business/industry }\end{array}$ & $\mathbf{x}$ & $x$ & & $\bar{x}$ & & $x$ & & $\mathbf{x}$ & $x$ & & & $\mathbf{x}$ & $x$ & & & $\mathbf{x}$ & & & $x^{2}$ & \\
\hline Combination of above & & & & & $\mathbf{x}$ & & & & & & $\mathbf{x}$ & & & & & & & & & \\
\hline
\end{tabular}

1 Preferred category

2 Considered less risky

$x$ indicates response

- indicates not applicable 
Table 3 General classification of past mergers/acquisitions

\begin{tabular}{|c|c|c|c|c|c|c|c|c|c|c|c|c|c|c|c|c|c|c|c|c|}
\hline & \multicolumn{20}{|c|}{ Respondent No. } \\
\hline & 1 & 2 & 3 & 4 & 5 & 6 & 7 & 8 & 9 & 10 & 11 & 12 & 13 & 14 & 15 & 16 & 17 & 18 & 19 & 20 \\
\hline Horizontal & $x$ & & & & & $x$ & $\mathbf{x}$ & $\mathbf{x}$ & $x$ & $x$ & $\mathbf{x}$ & $x$ & & $x$ & $x$ & $\mathbf{x}$ & $\mathbf{x}$ & $x$ & & $\mathbf{x}$ \\
\hline Vertical backwards & & $x$ & & & & $x$ & & $x$ & & & $\mathbf{x}$ & $x$ & & & $x$ & $x$ & & & & \\
\hline Vertical forwards & & & & & & $\mathbf{x}$ & & & & & & $\mathbf{x}$ & $\mathbf{x}$ & & & & & & & \\
\hline Concentric marketing & & & & & & & & & & & & & & & & & & & $x$ & \\
\hline Concentric technology & & $\mathbf{x}$ & & & & & & & & $\mathbf{x}$ & & & & & & & & & & \\
\hline Conglomerate & $x$ & & $\mathbf{x}$ & & $\mathbf{x}$ & & & & & & & & & & & & & & & \\
\hline Difficult to say & & & & $x$ & & & & & & & & & & & & & & & & \\
\hline
\end{tabular}

respondents deemed it unnecessary to consider the issue, leading to the conclusion that its presence in the acquisition profile is unwarranted. However, five respondents indicated their organizations had considered the amount available to devote to an acquisition programme. None of the five divulged a specific sum their organizations had set aside. This may be because many of the respondent organizations had access to virtually unlimited funds, either from parent companies, or existing operations. Nevertheless, two respondents indicated a maximum amount per transaction, in an endeavour to minimize the impact of a failed transaction, and thereby reduce risk. This could be considered a worthwhile approach, especially when viewed against a seemingly high failure rate in transactions.

\section{Location of business}

Respondents were requested to indicate whether or not the location of a potential candidate was important. Six indicated their organizations had included this criterion in their acquisition profiles, while eight indicated their organizations had not. Judging from the responses, it is clear that whether or not geographic location is important depends to a great extent on the spread of operations of the acquiror itself. Three of the respondents indicated they looked at both domestic and international acquisitions, although it was acknowledged that control and other difficulties presented themselves in such a situation. One respondent indicated that any potential candidate must 'be close to existing facilities', whilst another was adamant that only South African candidates were considered.

A third respondent indicated that location was important for many reasons, including tax, transportation, proximity to raw materials, and proximity to markets.

Whilst it is difficult to reach any definite conclusion from the research regarding location, a number of tentative suggestions can be made :

- generally speaking, it is less risky to acquire organizations close to existing operations - clearly, distance adds difficulty to management control, especially in troubled times;
- those organizations in the early stages of their acquisition programmes would do well to stay close to home; - the more geographically spread an organization becomes, the less important location becomes; and - location is not only important vis-a-vis the location of the acquiror other factors may be included such as tax, access to markets, raw materials, etc.

\section{Management policy}

Eleven respondents indicated their organizations had an espoused management policy included in their acquisition profiles. One consideration became almost the dominant theme of most of these stated policies: 'We seek good management, and retain it', was one way a respondent put it. Another reported: 'The management must be good - we hold on to existing management'. In fact seven of these eleven respondents, one way or another, said the same thing - management is crucial on acquisition, the management must be sound, and be retained. Hardly surprising, given the present dearth of good management in South Africa. These views accord with those of Willard F. Rockwell Jr, former Chairman of the Board of North American Rockwell Corporation:

'The corporate asset in shortest supply these days is good, skilled, experienced loyal management.

When you acquire a new company, the top leader-

ship that comes along with the package is at least as

important as the rest of the assets you buy.'

(Rockwell, 1968).

Compatibility was also mentioned by two respondents, who insisted that the management of any potential acquisition candidate should be compatible with their own management. This is obviously related to management retention - high compatibility is likely to facilitate retention. Two respondents were ressonably inflexible in this regard - acquired management were in effect given an ultimatum - fit in, or leave! Surprisingly, only one respondent specified the use of lucrative management contracts or share options to retain manage ment. This respondent expressed the view that the new perks tax in South Africa made the use of share options even more problematic than before. 
In conclusion, the responses elicited on management policy highlighted that most of the organizations had indeed developed a policy in this regard. Most had included these in their acquisition profiles. Three key areas were discovered: management retention; management compatibility; and management compensation/ remuneration. No doubt the three areas are interrelated, and effective implementation of a policy based on the view that management should be of a high quality and remain requires that :

- a method of evaluating the quality or 'goodness' of the management of a potential candidate exists - those organizations who make acquisitions and insist that incumbent management remain must have the ability to evaluate such management; and

- the nature and style of the management of the acquiror is known beforehand, and a method of evaluating the nature and style of the management of a potential candidate exists - obviously before the compatibility of the two managements can be judged, these two factors must be evaluated and known.

These two aspects were explored in greater depth in Sections Two and Three of the questionnaire, and will be dealt with in full in another article.

\section{Return on investment policy}

Modern financial theory holds that an investment is 'the sacrifice of present consumption for the hope of future gain'. Acquiring a business is no different - in effect the acquisitor acquires a capital asset (the business, usually represented by the acquisition of ordinary shares) - and hopes that over time this asset will provide an acceptable return. Any acquisitor, therefore, needs to confront this issue - what return on investment is required from a potential acquisition candidate. In a sense, the question asked on this aspect of the acquisition profile was a 'trick' question - modern financial theory also holds that return cannot be judged in isolation - in fact, it is incorrect to set one acceptable rate of return (say 25\% after tax) which all potential candidates should offer before being considered. This is because return is related to risk - the higher the risk, the higher the return which should be expected from the particular investment under consideration.

One required rate of retum is only valid where all potential acquisition candidates exhibit the same degree of risk, a situation which is unlikely to occur often in practice. This leads to the conclusion that the only correct return on investment policy is one which states 'it depends'. In other words, the return required should depend on the evaluation of the risk displayed by each prospective candidate. This aspect should therefore only be confronted at the evaluation state, and has no place in the acquisition profile itself.

Thirteen of the fourteen respondents who indicated their organizations had developed an acquisition profile reported that a stated return on investment policy was included in their profiles. Of these thirteen:

- six indicated a fixed required rate of return, ranging from $15-35 \%$ per annum after tax;
- two respondents reported their policy varied, and was a function of risk;

- one respondent indicated his policy depended on the interest rates and cost of funds at the time.

It is not the intention of this article to address in depth the issues of risk and return when related to mergers and acquisitions. However the research has highlighted misdirection and misunderstanding in this regard - only two of the thirteen respondents indicated an awareness of the risk/return relationship. Apparently, the theory and the practice diverge in this instance. Any organization embarking upon an acquisition programme would do well to realize that return is a function of risk; religious adherence to one mystical rate of return which all acquisitions should at least meet is misdirected and incorrect. Furthermore, risk, and therefore return, are relative measures, which depend upon the risk/return combinations offered by alternative investment opportunities. A change in interest rates, in theory, should alter the return expectations on other investments. This provides even further rationale for disregarding the use of a single magical required rate of return for all acquisitions, for a long period of time.

\section{Minimum/maximum size of investment criteria}

Ten of the fourteen respondents who indicated their organizations had developed explicit acquisition profiles indicated their profiles contained criteria relating to the minimum/maximum size of investment. Seven of these ten respondents were of one mind: 'no maximum only a minimum' was one way a respondent put it. 'Small companies are a waste of management time' was the view of another. Whilst 'smallness' may well be a question of degree and relativity, the majority of respondents agreed on this point do not even consider looking at companies which you define as small. Some based size on profits before $\operatorname{tax}$ - a profit before tax of less than $\mathbf{R} \mathbf{l}$ million was considered small by one organization; others limited size according to turnover - a turnover of less than R4 million was the limit decided by one, R25 million by another; a different approach was used by a third organization - it related size to its own turnover, specifying that any potential candidate had to have a turnover of at least $10 \%$ of its own. Even another variation was discovered - one organization refused to make an investment of less than R10 million. Significantly, only one of the ten respondents had a maximum size limit - it refused to invest more than R5 million in any one transaction.

No doubt the research findings regarding minimum/ maximum size of investment criteria are biased because the sample is mainly representative of substantial listed companies. But the message is clear-organizations should be wary of acquiring other organizations very much smaller than themselves. The management time and effort required to negotiate and implement such a transaction, and indeed to correct matters should the acquisition go awry, is usually exorbitant. This is in accord with the theory. Both Kitching (1967) and 
Rowlinson (1984) attributed size mismatch a major cause of merger/acquisition failure.

This concludes the discussion on the research findings with regard to the determination of an acquisition strategy. Broadly speaking, the findings show that most of the respondents were aware of the issues requiring attention in determining and setting a merger/acquisition strategy: $70 \%$ of the sample (fourteen) had developed an acquisition profile; most had considered a majority of the criteria included in the questionnaire. The only criterion leaving cause for concern was the retum on investment policy, for the reasons stated above. But what of the respondents' perceptions of the viability of such a strategy? The remainder of the article will consider the issue.

\section{Growth through mergers and acquisitions: viability and critical success factors}

As noted above, even a superficial scan of recent literature on mergers and acquisitions leads to one conclusion: chances of success are slim. Some may even contend this is no longer a moot point - all that now requires establishing is why. This quest was begun in the late sixties, and since then many reasons have been advanced. Kitching (1967) listed a number of reasons: size mismatch, more specifically where the acquired company's sales were less than $2 \%$ of the acquiror; breakdown in reporting relationships or restriction in operational autonomy; the absence of 'managers of change' in the acquiring organization to catalyse and implement the transaction; the failure to formulate and abide by a set of acquisition criteria consistent with overall strategy; and 'ad hoc' reactive responses to proposals. Rockwell (1968) listed ten commandments of successful merger/acquisition practice. These included pin-pointing the transaction objectives; ensuring that the candidate's management is competent; involving the chief executive of the acquisitor in the acquisition programme; clearly defining the business you are in; understanding in depth both your organization's and the acquisition candidate's strengths, weaknesses and key performance factors; and making people your number one consideration - absorbing people with care. Levinson (1970) ascribed major reasons for failure to psychological reasons, including fear and anxiety on the part of employees of the acquired organization, and condescending attitudes on the part of the acquiror's management. To these reasons many can be added, including overhasty consummation; culture mismatch; inadequate evaluation and insufficient implementation planning; and inadequate resources to manage change.

One of the objectives of the research was to record the respondent's views on this issue. In an open ended question, respondents were asked to express why, in their views, mergers or acquisitions failed. Some perceptive insights were obtained. Many of the reasons were related to inadequacies within the acquiring organization itself. These included :

- an unprofessional approach to mergers and acquisitions, including insufficient evaluation and a lack of homework (mentioned by eight respondents);
- transactions undertaken for the wrong reasons/ motivation (mentioned by five respondents); and

- lack of experience in mergers and acquisitions (mentioned by one respondent).

Eight respondents cited culture clash/management incompatibility as reasons for failure. Going outside the organization's area of expertise/technology was listed by three respondents; whilst failure to resolve/develop appropriate reporting structures was listed by four respondents.

Many other reasons were advanced. Significantly, only one respondent listed poor cash flow as a reason, and no reasons related to the business failure of an acquisition itself. Overwhelmingly, almost all of the just over fifty individual reasons advanced related to strategy formulation, lack of inhouse management expertise, and the evaluation and management of people. Perhaps this last point is best summed up by one respondent who said 'Acquisitions fail when the acquiror forgets he is acquiring people, and not just shares in the business.'

Respondents were also asked to list what they considered critical success factors in the merger/acquisition process. To a great extent these factors represented the converse of the reasons for failure. The major critical success factors advanced were :

- investigate, evaluate and understand in depth the business you are acquiring;

- establish a relationship of trust between the two managements as soon as is possible;

- either ensure that the management of a candidate is competent and compatible, or have management to replace it; and

- ensure that reporting systems are appropriate and adequate, but beware of overkill.

Respondents were also requested to estimate, in their view, the percentage of mergers or acquisitions which were 'successful'. No attempt was made to define success. Respondents were also asked to estimate the percentage of candidates divested. Table 4 presents the research findings in this regard.

It should be noted that the figures contained in Table 4 are estimates, and represent little more than a measurement of perceptions. Thirteen of the twenty respondents considered more than $40 \%$ of transactions as successful; whilst surprisingly, $25 \%$ of the sample rate more than $90 \%$ of transactions as 'successful' - substantially different from many of the views cited at the beginning of this article.

Regarding percentage divested, $70 \%$ of the sample indicated that $20 \%$ or less of transactions were divested, also a far more acceptable statistic than those mentioned previously.

Respondents were also asked whether or not certain mergers or acquisitions were more successful than others. Seventeen respondents said yes, two no, and one found it difficult to say. Those who said yes were asked, in an open ended question, to state which were more successful. Quite understandably, respondents rated the following types of mergers or acquisitions as more successful : 
Table 4 Percentage of mergers/acquisitions considered successful/divested

\begin{tabular}{lcc}
\hline Percentage & $\begin{array}{c}\text { Considered succescul } \\
\text { No.of respondents }\end{array}$ & $\begin{array}{c}\text { Diverted } \\
\text { No.of respondents }\end{array}$ \\
\hline $0-20$ & 2 & 14 \\
$21-40$ & 2 & 3 \\
$41-50$ & 5 & 1 \\
$51-60$ & 1 & - \\
$61-80$ & 2 & - \\
$81-90$ & - & - \\
$91-100$ & 5 & 2 \\
Difficult & & \\
to say & 3 & \\
\hline
\end{tabular}

- those whose business and industry is well known and understood by the acquiror (five respondents);

- horizontal mergers or acquisition (five respondents);

- those where the culture is compatible (three respondents).

A number of other reasons were advanced, including those where the candidate had established market share, a sound base and no prima donna managers; those planned in advance with the potential established; those where $100 \%$ of the equity was acquired immediately; and those where the candidate had a positive cash flow.

Respondents were also asked to state whether or not some types of transactions are less likely to be successful. Whilst most responses represented the converse of those most likely to be successful, a number of additional probable causes of 'less' success were highlighted: 'Conglomerate' type mergers or acquisitions were listed by three respondents as less likely of success; two specifically mentioned bargains as less likely of success 'Acquire winners ... and pay for them' was the attitude of one respondent; two respondents also rated those transactions done in a hurry as less likely of success.

Finally, respondents were questioned as to whether they considered growth by mergers and acquisitions a low, medium or high risk strategy. Their responses are listed in Table 5.
As can be seen, the responses were varied: seven considered such a strategy a low risk strategy only; three considered it a medium risk only; whilst six considered it a high risk strategy only. Three respondents considered it a combination of low, medium and high; whilst one respondent found it difficult to say. Respondents were asked to expand their views in this regard.

Three of the seven respondents who considered the strategy a low risk strategy only qualified their view by stating this was only the case where candidates were properly investigated, and the business/industry of the acquired company was well known. Another respondent who indicated it was a low risk strategy said this was only the case provided the sales of the acquired company were restricted to less than $20 \%$ of the acquiror, and provided a thorough investigation was done.

One of the three respondents who indicated it could be a low, medium or high risk strategy said this depended on the approach adopted by the acquisitor - clearly in his view, a professional approach reduced risk. The second of the three candidates who opted for all three risk classes said this depended on the type of transaction concluded: horizontal transactions were low risk, vertical medium risk, and conglomerate high risk .

One respondent who considered the strategy a medium risk warned of the downside where inadequate planning or evaluation was done, the downside could be substantial. Comparing this strategy with others, two respondents felt it was less risky than starting from scratch, whilst two who assigned the strategy a high risk class attributed this to the high risk of failure, and the management skills required to manage the transaction afterwards, which skills in this respondent's view. seemed scarce.

\section{Conclusion}

To be honest, when this research was commenced, it was expected that the findings would do little more than add to the already daunting collection of horror stories and nightmarish tales that haunt the literature about mergers and acquisitions. Refreshingly, if not surprisingly, this has not been the case. If nothing else, the research has shown that growth through mergers and acquisitions can indeed be a viable and successful strategy. The organizations surveyed confirmed that by and large their merger and acquisition programmes have been successful. Certainly the negativity encountered by many other

Table 5 Growth by mergers and acquisitions strategy: Risk classification

\begin{tabular}{|c|c|c|c|c|c|c|c|c|c|c|c|c|c|c|c|c|c|c|c|c|}
\hline \multirow{2}{*}{ Riok class } & \multicolumn{20}{|c|}{ Respondent No. } \\
\hline & 1 & 2 & 3 & 4 & 5 & 6 & 7 & 8 & 9 & 10 & 11 & 12 & 13 & 14 & 15 & 16 & 17 & 18 & 19 & $\mathbf{2 0}$ \\
\hline Low & $\mathbf{x}$ & $x$ & & & & $x$ & & $x$ & $x$ & & & & & $\mathbf{x}$ & & & $\mathbf{x}$ & $x$ & $\mathbf{x}$ & $x$ \\
\hline Modium & & $\mathbf{x}$ & & & & & & & & $x$ & & $x$ & & $\mathbf{x}$ & $\mathbf{x}$ & & & & $\mathbf{x}$ & \\
\hline High & & $x$ & $\mathbf{x}$ & $\mathbf{x}$ & $x$ & & $x$ & & & & $x$ & & $\mathbf{x}$ & $x$ & & & & & $x$ & \\
\hline Difficult to say & & & & & & & & & & & & & & & & $\mathbf{x}$ & & & & \\
\hline
\end{tabular}


researchers was in the main absent from this study. This could be attributed to the fact that most acquisitions undertaken by the organizations represented were either horizontal or vertical integration, two types of transactions which are less risky and more likely of success. Conversely, it could be argued that the respondents themselves had a vested interest in presenting such a picture - those who conceive and execute a strategy may be unwilling to admit to its faihure. This is, however, doubtful. To question in such a fashion would be nothing less than questioning the integrity of the senior executives involved in the study. Others may contend that only those with happy experiences may have been prepared to talk about them. To this shortcoming a firmer answer can be given. Firstly, the research does not claim to be representative of all South African acquisitors. Secondly, at least it has been shown that some organizations can successfully grow through merger or acquisition. Why not learn from their experiences?

Notwithstanding any doubts which could be raised concerning the research methodology and findings, the research has highlighted a number of factors which fledgling acquisitors would do well to take into account before embarking upon a growth through mergers and acquisitions strategy. These factors include :

- corporate growth through mergers and acquisitions can be either a viable strategy, or a road to ruin. A systematic, structured and planned approach to the process of creating corporate wealth through mergers and acquisitions can ensure viability and success;

- successful mergers or acquisitions do not just happen

- they have to be skillfully managed, and guided;

- an unprofessional or 'ad hoc' approach to mergers and acquisitions is likely to result in disaster for all parties involved; and

- the risks involved in adopting a strategy of growth through merger or acquisition can be greatly reduced by incorporating the findings of this and other research into corporate strategies and practices.

\section{References}

Blake R.R. \& Mouton J.S. 1984. Solving costly organizational conflicts: Achieving intergroup trust, cooperation and teamwork. San Francisco: Jossey-Bass Inc.

Farrant P. 1970. The truth about mergers. Manage. Today, p. 120.

Foulder I. \& Gill J. 1978. Managing a merger: The acquisition and the aftermath. Pers. Manage., vol.10, 14-17.

Jacobs B.A. 1984. Handyman on mergers. Ind. Week, vol.220, p.50.

Kitching J. 1967. Why do mergers miscarry? Harv. Bus. Rev. vol. 45, 84- 101.

Leighton C.M. \& Tod G.R.1969. After the acquisition: continuing challenge. Harv. Bus. Rev., vol.47, 90-102.

Levinson H. 1970. A psychologist diagnoses merger failure. Harv. Bus. Rev., vol.48, 139-147.

MacGregor I.H. 1979. Mergers, acquisitions and Shareholders. lst edition. Cape Town: Juta and Co Ltd.

Peters T.J. \& Waterman R.H. 1982. In search of excellence. New York: Harper \& Row.

Rappaport A.J. 1979. Strategic analysis for more profitable acquisitions. Harv. Bus. Rev., vol.57, 121-132.

Reich R.S. 1983. The next American Frontier. lst edition. New York: Time Books.

Robinson E.A.G. 1958. The structure of competitive industry. Cambridge: Cambridge University Press.

Rockwell W.F.Jr. 1968. How to acquire a company. Harv. Bus. Rev., vol.46, 121-132.

Rowlinson C.E. 1984. The change in the performance of a small business acquired by a large corporation. Unpublished research thesis, University of the Witwatersrand, Johannesburg.

Searby F.W. 1969. Control postmerger change. Harv. Bus. Rev., vol.47,p.4.

Swaim R.W. 1985. Merger - the personnel squeeze. Pers. J., vol. $74,34-40$.

Willensky D.R. 1985. Making it happen: How to execute an acquisition. McKinsey Q., 77-91. 